\title{
Late Pleistocene barrier-island sequence along the southern Delmarva Peninsula: Implications for middle Wisconsin sea levels
}

\author{
Kenneth Finkelstein \\ Virginia Institute of Marine Science \\ Michael S. Kearney
}

Follow this and additional works at: https://scholarworks.wm.edu/vimsarticles

Part of the Geology Commons

\section{Recommended Citation}

Finkelstein, Kenneth and Kearney, Michael S., Late Pleistocene barrier-island sequence along the southern Delmarva Peninsula: Implications for middle Wisconsin sea levels (1988). Geology, 16(1), 41-45. https://scholarworks.wm.edu/vimsarticles/2186 


\title{
Late Pleistocene barrier-island sequence along the southern Delmarva Peninsula: Implications for middle Wisconsin sea levels
}

\author{
Kenneth Finkelstein* \\ Virginia Institute of Marine Science, School of Marine Science, College of William and Mary, Gloucester Point, Virginia 23062 \\ Michael S. Kearney \\ Laboratory for Coastal Research and Department of Geography, University of Maryland, College Park, Maryland 20742
}

\section{ABSTRACT}

Evidence for a middle Wisconsin sea-level high at or above modern limits along the east coast of the United States has long been controversial. Most reports have been dismissed as poorly dated or lacking unequivocal documentation of a marine transgression. We 02173 .

*Present address: 1475 Massachusetts Avenue, Lexington, Massachusetts

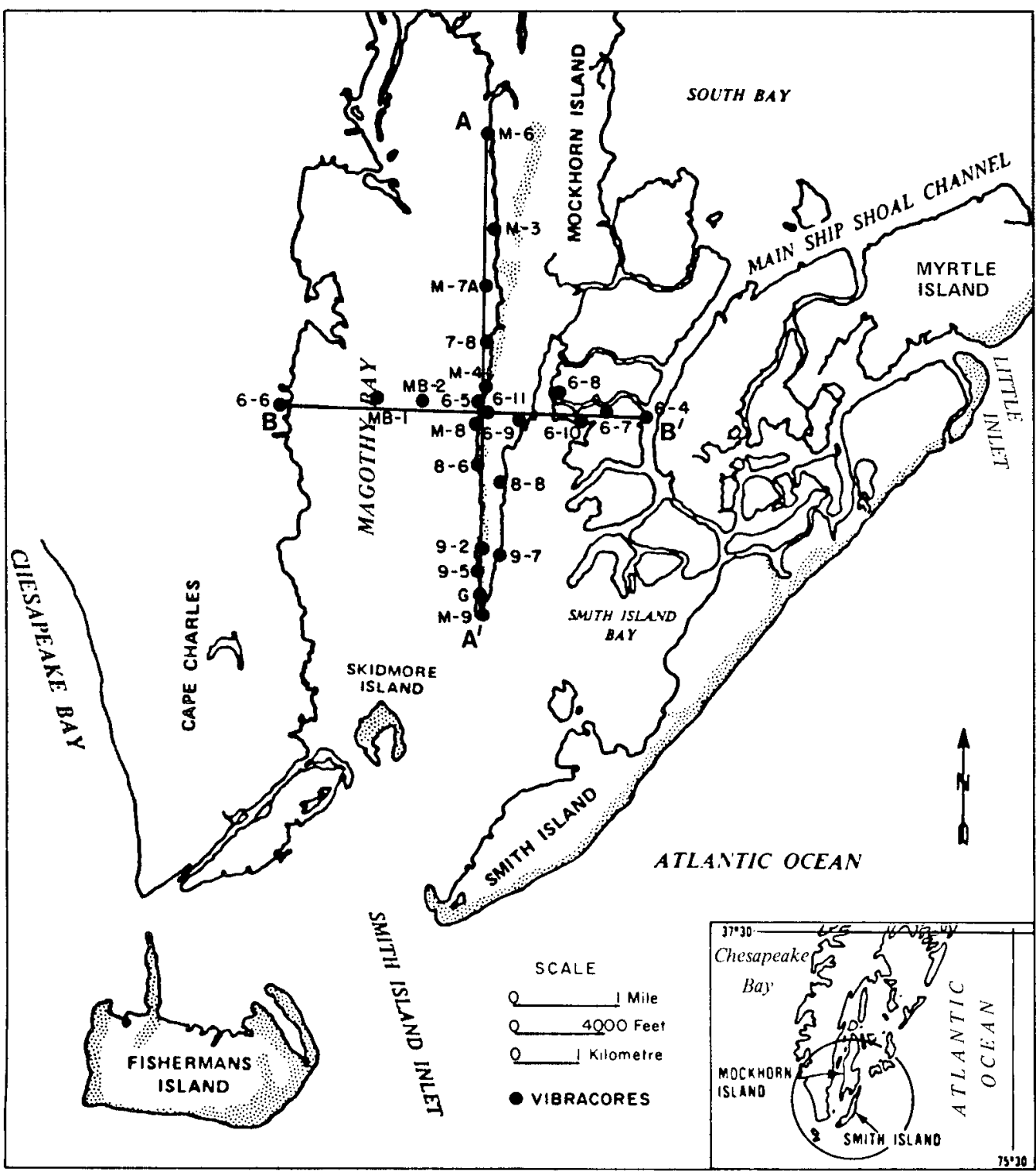

describe here a ${ }^{14} \mathrm{C}$-dated, middle Wisconsin transgressive sequence with an extant subaerial barrier facies along the southern Delmarva Peninsula. This sequence indicates that sea levels were near their present position between ca. 23 and $34 \mathrm{ka}$; it may correlate with other inferred similar-age littoral deposits of the area, and it suggests that the evidence for glacioeustatic fluctuations during the Wisconsin Glaciation should be reconsidered.
Figure 1. Location of Mockhorn Island and its relation to adjacent Holocene barrier islands along southern Delmarva Coast. Dots indicate vibracore sampling sites, and straight lines indicate location of transects in Figure 2. 


\section{INTRODUCTION AND GEOMORPHIC SETTING}

Emerged late Pleistocene transgressive sequences have been widely described along the United States Atlantic and Gulf coasts. Few reliable dates are available for these deposits, but uranium-series and amino-acid racemization age estimates on some deposits (Belknap and Wehmiller, 1980; Cronin et al., 1981) suggest that most are probably Sangamon in age. Nevertheless, reports of younger, middle Wisconsin age barriers and associated facies (Susman and Heron, 1979; Moslow, 1980) are common in the literature; the most notable is the Silver Bluff shoreline of Hoyt and Hails (1974) tentatively dated between ca. 25 and $37 \mathrm{ka}$. Further complicating the picture of late Pleistocene sea levels are the controversial sealevel curves of Curray (1965), Milliman and Emery (1968), and, most recently, Blackwelder et al. (1979). These sea-level curves all portray sea levels near modern limits between ca. 25 and $40 \mathrm{ka}$, though criticisms have focused on sample selection and dating methods (cf. Bloom, 1983).

Thom (1973) devised five criteria for evaluating ${ }^{14} \mathrm{C}$ dates supporting late Pleistocene sea levels, including clear geomorphic and stratigraphic evidence for a transgression, in situ collection of dated materials, and appropriate sample pretreatment for ${ }^{14} \mathrm{C}$ dates and cross-verification with other dating techniques. A step toward meeting these criteria and resolving some of the problems of sea-level position during the middle Wisconsin would be the documentation of a well-dated, stratigraphically complete sequence with an unequivocal barrier facies.

Mockhorn Island (Fig. 1) is a low, partially vegetated sand ridge (maximum elevation above sea level, $2 \mathrm{~m}$ ) located near the southern tip of the Delmarva Peninsula, approximately midway between the mainland and Smith and Myrtle islands of the Virginia barrier-island chain. This narrow ( $<300 \mathrm{~m}$ average width) island, in contrast to the nearest modern barrier, parallels the mainland and is surrounded by Holocene age backbarrier bays, tidal flats and creeks, and marshes. Previous studies (Shideler et al., 1984), corroborated by archeological evidence of human occupation prior to the late Holocene submergence of the area (K. Egloff, 1982, personal commun.), have interpreted Mockhorn Island as a coastal barrier formed during a late Pleistocene sea-level highstand. Cores from fringing marshes on the mainland (Finkelstein, 1986) indicate that the barrier correlates with the undated upper Wachapreague Formation and thus postdates the lower sand and silt unit of this deposit, which uranium-series and amino-acid dating methods suggest is of early Wisconsin/Sangamon
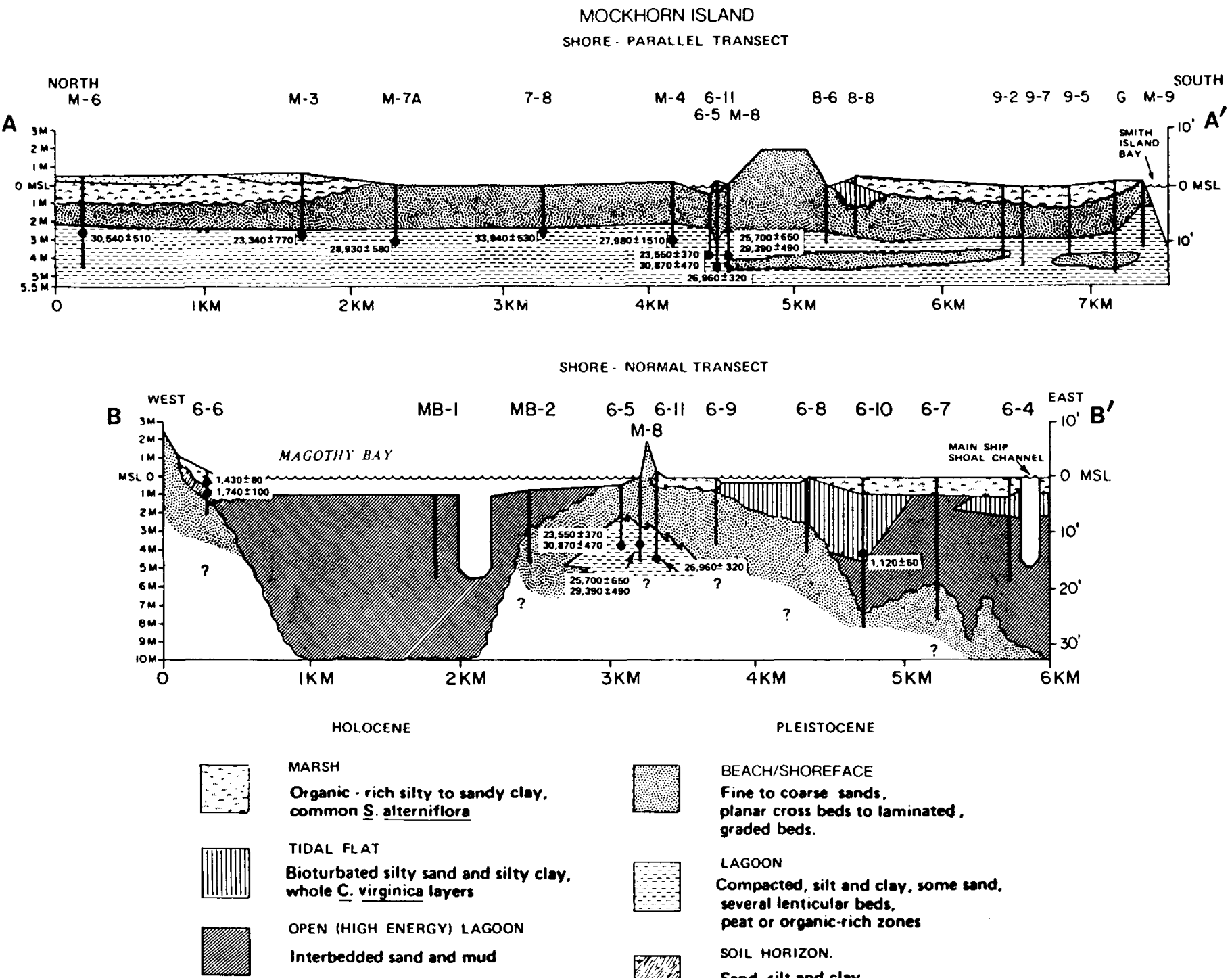

MARSH

Organic - rich silty to sandy clay. common $\underline{\text { S. alterniflora }}$

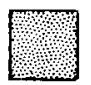

BEACH/SHOREFACE

Fine to coarse sands. planar cross beds to laminated. graded beds.

TIDAL FLAT

Bioturbated silty sand and silty clay. whole $\mathrm{C}$. virginica lavers

LAGOON

Compacted, silt and cley, some sand. several lenticular beds. peat or organic-rich zones

OPEN (HIGH ENERGV) LAGOON

Interbedded sand and mud

SOIL HORIZON.

Sand, silt and clay.

terrestrial vegetation

Figure 2. Shore-parallel (transect A-A') and shore-normal (transect B-B') reconstructions of stratigraphic relations of Mockhorn barrier facies to Holocene and dated Pleistocene lagoonal deposits in area. Thick vertical lines indicate locations of coring sites; dots show depth of ${ }^{14} \mathrm{C}$ samples. Stratigraphic changes in areas without vibracores are based on seismic surveys (Finkelstein, 1986). 
age (Mixon, 1985). In this paper we examine in detail the stratigraphy and dating of Mockhorn Island and discuss its implications for late Pleistocene sea levels and tectonics of the mid-Atlantic continental margin.

\section{STRATIGRAPHY, AGE, AND PALYNOLOGY}

Detailed study of the stratigraphic relations of late Pleistocene deposits to Holocene sediments of the area was undertaken; vibracores and high-resolution, subbottom seismic surveys were used (Finkelstein, 1986; Fig. 1). The data show that Mockhorn Island forms part of a continuous pre-Holocene sand sheet ( $>3.5 \mathrm{~m}$ thick) extending over $4 \mathrm{~km}$ (Fig. 2). The sands gradually dip seaward below disconformably overlying Holocene back-barrier tidal-flat, lagoon, and lagoonal marsh deposits. Toward the mainland the sands are overlain by a thicker sequence of sandy lagoonal deposits. Sedimentologic analyses reveal the Mockhorn sand facies to be iron stained and coarser than sand facies of the nearest Holocene barrier, Smith Island (1.81 $\phi$ mean grain size versus $2.31 \phi$; Fig. 1); the Mockhorn sand facies has interspersed heavy mineral laminae between planar, mostly horizontal beds. In several cores from the island (e.g., M-7A; Fig. 1), evidence of a former surface can be recognized from a truncated paleosol buried beneath reworked Holocene foreshore sands.

The Mockhorn sand facies conformably overlies compacted clayey silts and scattered lenticular sand beds, intercalated peaty clays, and occasional shoal-like sand bodies that probably represent flood-tidal deltas (Fig. 3). The relatively homogeneous grain-size distributions of the mud

\begin{tabular}{|c|c|c|}
\hline MUD & \multicolumn{2}{|c|}{ SAND } \\
\hline $\begin{array}{ll}C & S \\
\text { L } & 1 \\
A & L \\
Y & \text { L }\end{array}$ & $\begin{array}{c}F \\
i \\
N\end{array}$ & $\begin{array}{l}M \\
E \\
D\end{array}$ \\
\hline
\end{tabular}
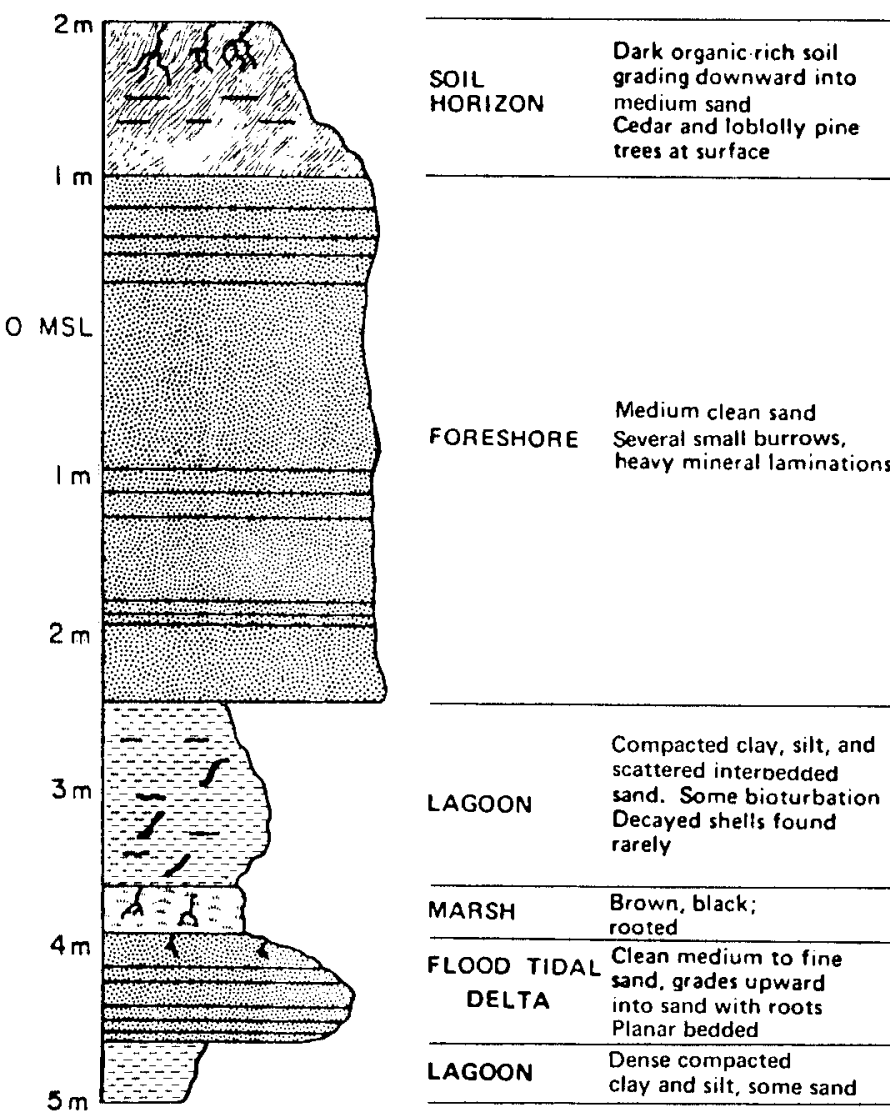

igure 3. Composite stratigraphic sequence of Mockhorn Island (based on cores M-8, 6-5, and 6-8; see locations in Fig. 1). samples, characteristic tabular bedding, and occurrences of both calcareous (e.g., Elphidium sp.) and agglutinated foraminifera compare well with analyses of modern back-barrier lagoonal sediments of the area (cf. Shideler et al., 1984). Salinities for this faunal assemblage along the southern Delmarva coast are inferred to range from about $15 \%$ to $25 \%$ (Shideler et al., 1984). Contacts between the Mockhorn sand and mud facies also are nearly identical to those found beneath the modern transgressive barrier, Smith Island. The close similarities of the Mockhorn stratigraphic sequence and facies-environment relations to the adjacent Holocene barriers thus strongly support the interpretation that they were the result of a former marine transgression.

Ten finite ${ }^{14} \mathrm{C}$ dates on the peaty clays in the lagoonal muds indicate a middle Wisconsin age (Table 1). Pollen analyses of these and undated but stratigraphically adjacent peaty clays reveal a flora dominated by pine, spruce, birch, grasses, and Sphagnum, and spruce constitutes between 5\% and $11 \%$ of the pollen sum (Fig. 4). Size measurements of spruce and pine grains (Birks and Peglar, 1980; Whitehead, 1981) and indicator pollen taxa suggest that the regional vegetation was mostly a boreal assemblage represented by both white spruce (Picea glauca) and black spruce (Picea mariana), jack pine (Pinus banksiana), fir (Abies sp.), and oak (Quercus), and an understory of ericads, composites, and such northern herbs as Thalictrum and Lycopodium annotium. Similar pollen assemblages, reliably dated between ca. 20 and $30 \mathrm{ka}$, have been reported from the central Delmarva Peninsula (Sirkin et al., 1977) to as far south as northeast North Carolina (Whitehead, 1981). Comparison with modern analogues suggests that these and the Mockhorn assemblages record a cool-cold, moist interstadial climate, annual temperatures being perhaps $10^{\circ} \mathrm{C}$ lower than today (Whitehead, 1981).

Mockhorn Island was formed by a transgression that possibly began as early as ca. $35 \mathrm{ka}$. Although lagoonal foraminifera occur above and below the dated peaty clays, pollen data, characterized by Sphagnum, birch, and other wetland and aquatic taxa (e.g., Potamogeton, Myrica, and Typha), document that some freshwater to perhaps moderately brackish environments persisted in the area until shortly after $29 \mathrm{ka}$. Stratigraphically younger samples (e.g., M-8), dated between ca. 23 and $28 \mathrm{ka}$, contain

TABLE 1. MIDDLE WISCONSIN ${ }^{14} \mathrm{C}$ DATES FROM MOCKHORN

\begin{tabular}{|c|c|c|c|c|}
\hline Core no. & $\begin{array}{l}\text { Depth } \\
\text { below } \\
\text { MSL* } \\
(\mathrm{cm})\end{array}$ & Lab no. & Material & $\begin{array}{l}{ }^{14} \mathrm{C} \text { age } \\
\mathrm{ka} \pm 1 \delta\end{array}$ \\
\hline $6-5$ & 370 & \multirow{2}{*}{$\begin{array}{l}\text { Beta-1949 } \\
\text { Beta-3423 } \\
\text { Beta-6669 } \\
\text { Beta-5033 }\end{array}$} & Peaty clay & \multirow{2}{*}{$\begin{array}{l}23.55 \pm .37 \\
30.87 \pm .47 \\
26.96 \pm .32 \\
33.94 \pm .53\end{array}$} \\
\hline $\begin{array}{l}6-11 \\
7-8\end{array}$ & $\begin{array}{l}455 \\
250\end{array}$ & & $\begin{array}{l}\text { Organic debris } \\
\text { Peat/organic-rich } \\
\text { mud }\end{array}$ & \\
\hline$M-3$ & 260 & Beta-5030 & $\begin{array}{l}\text { Peat/organic-rich } \\
\text { mud }\end{array}$ & $23.34 \pm .77$ \\
\hline$M-4$ & 300 & Beta-5032 & $\begin{array}{l}\text { Peat/organic-rich } \\
\text { mud }\end{array}$ & $27.98 \pm 1.51$ \\
\hline $\begin{array}{l}M-6 \\
M-7 A \\
M-8\end{array}$ & $\begin{array}{l}250 \\
254 \\
380\end{array}$ & $\begin{array}{l}\text { Beta- } 6671 \\
\text { Beta-6672 } \\
\text { Beta- } 6670 \\
\text { Beta- } 6673\end{array}$ & $\begin{array}{l}\text { Peaty clay } \\
\text { Peaty clay } \\
\text { Peaty clay }\end{array}$ & $\begin{array}{l}30.54 \pm .52 \\
28.93 \pm .58 \\
25.70 \pm .65 \\
29.39 \pm .49\end{array}$ \\
\hline
\end{tabular}

Note: Pretreatment of peaty clays and other organic horizons consisted of picking out apparent rootlets, eliminating carbonates with hot $\mathrm{HCl}$, and repeated rinsing to neutrality. Dates are reported using the Libby half-life of $5568 \pm 30 \mathrm{yr}$, with $95 \%$ of the activity of the National Bureau of Standards 0xalic Acid as the modern standard. The lack of overlap in the error bars of replicates samples reflects expectable variations in radiocarbon age due to minor age differences of organic materials within the dated horizon (M. Tamers, Beta Analytic, Inc., 1986, personal commun.).

* Mean sea level 
abundant gonyaulacoid dinoflagellate cysts and the open-shelf foraminifer Elphidium (averaging 11 specimens per gram dry weight; cf. Poag et al., 1980 ), portraying marginal marine conditions and culmination of the transgression. The elevation of sea levels at the time compared to the Holocene barriers cannot be deduced simply from the more landward displacement of Mockhorn Island because of the relatively low gradient of the shelf profile in the area. Fossil decapod (Callianassa) burrows, which occur sporadically in the barrier beach sands up to just below the modern mean high-tide level, nonetheless imply that maximum sea levels stood near present mean sea level (cf. Weimer and Hoyt, 1964).

\section{CORRELATION AND IMPLICATIONS}

Correlation of the Mockhorn sequence with the extensive late Pleistocene marine terraces of this region of the U.S. mid-Atlantic Coast is not clear. Most of the more prominent scarps, given elevation and stratigraphic relations, are probably of Sangamon age, a fact borne out by available uranium-series dates (Owens and Denny, 1979; Cronin et al., 1981; Mixon, 1985). However, possible Wisconsin age shorelines, inferred from both stratigraphic position and geomorphic relations, have been described for parts of the Maryland and Virginia coasts. Marginal marine sands, forming a low-relief plain (maximum elevation above sea level, $1.5 \mathrm{~m}$ ) along the Maryland coast to Bethany Beach, Delaware, have been interpreted as marking a major transgression during the middle Wisconsin, ca. 30 ka (Owens and Denny, 1979). Pollen assemblages from this unit, characterized by abundant spruce pollen and indicating cool-cold conditions, suggest a post-Sangamon age. Mixon (1985), however, has argued that these sediments possibly correlate with the undated upper unit of the Wachapreague Formation, which he believed to be a regressive sequence formed during the late Sangamon/early Wisconsin regression. More problematical is the age of low ridge and swale features, the putative remnant barrier-lagoonal deposits of the old (latest Pleistocene[?]) Sandbridge
Formation of Oaks and Coch (1973). These features, renamed the Poquoson Member of the Tabb Formation by Johnson (1976), are up to $1.5 \mathrm{~m}$ above mean sea level and may be temporally equivalent to the Mockhorn facies. In addition, they and the Mockhorn barrier are seaward and lower in elevation than the $72 \mathrm{ka}$ shoreline described by Cronin et al. (1981) and Szabo (1985) from northeastern North Carolina. Nevertheless, as Cronin (1981) noted, correlation of former shorelines by altitude considerations alone can be misleading.

Models for late Pleistocene sea-level fluctuations are based largely on dating of high-level coral reefs in Barbados and New Guinea (Bloom, 1983). These reef-complex records, though differing in details, imply that world sea levels stood between about -38 and $-42 \mathrm{~m}$ (below present) during middle Wisconsin time. Moreover, to a large degree, these models are generally corroborated by deep-sea oxygen-isotope estimates of terrestrial ice volumes during the Wisconsin Glaciation (Shackleton and Opdyke, 1973). Both lines of evidence have been cited in prima facie rejection of reports of middle Wisconsin high sea levels, but they are not without their own problems. Nunn (1986) has shown that the Barbados and New Guinea sea-level curves may have been influenced by large-scale geoidal anomalies (up to $60 \mathrm{~m}$ ), and not by strictly glacioeustatic changes. Other criticisms have concerned the reliability of continental ice volumes estimates derived from the deep-sea cores (e.g., Ruddiman and McIntyre, 1981; Williams et al., 1981). If, however, the picture of late Pleistocene sea levels indicated by high-level reefs can be considered substantially correct, the occurrence of Mockhorn Island and other inferred middle Wisconsin age littoral deposits near modern sea level along the U.S. middle and southern Atlantic coasts must be explained in other than eustatic terms.

Cronin (1981) extensively reviewed possible mechanisms of late Cenozoic neotectonic uplift along the southeastern U.S. Atlantic Coastal Plain. Lithospheric flexure, i.e., coastal uplift due to crustal loading of the Carolina Trough by the thick wedge of Mesozoic and Tertiary sediments,

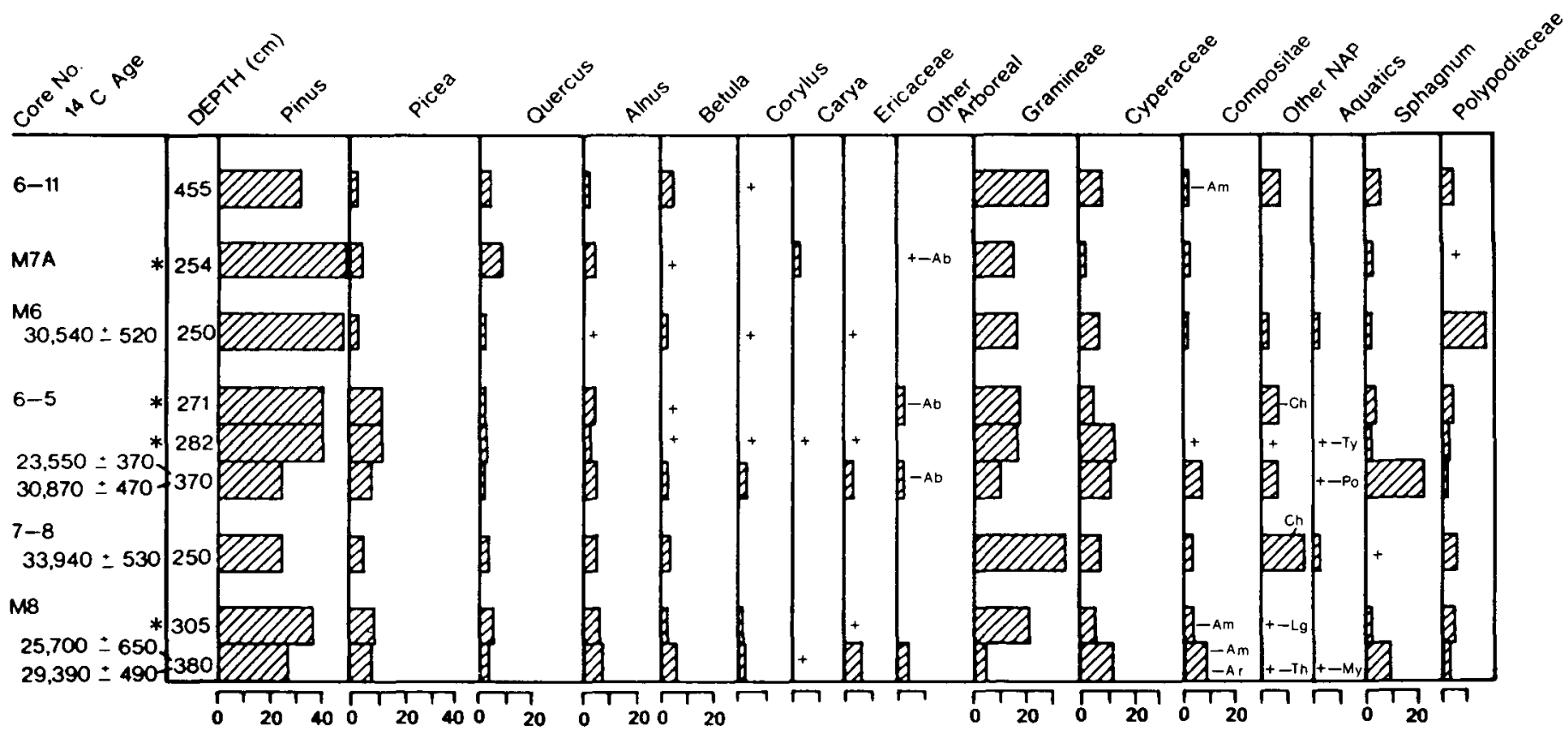

Percentage

Figure 4. Pollen assemblages of dated samples and adjacent levels in lagoonal deposits underlying Mockhorn Island (only representative dates are shown; others are listed in Table 1). Pollen sums are based on at least 200 arboreal grains. Ab = Abies; Am = Ambrosia; Ar = Artemisia; Ch = Chenopodiaceae; Lg = Leguminosae; My = Myrica; Po = Potamogeton; Th = Thalictrum; Ty = Typha; + = trace sample, * = presence of dinoflagellates. 
is believed to be the principal mechanism of long-term uplift in this region. Unfortunately, rates of uplift from lithospheric flexure average about 1-3 $\mathrm{cm} / 1000 \mathrm{yr}$ (Cronin, 1981) and are clearly too low to raise marginal marine deposits of middle Wisconsin age along these coasts to present sea-level position, given the constraints of the Barbados and New Guinea sea-level curves. Moreover, in the specific case of Mockhorn Island, its proximity to the Baltimore Canyon Trough, the major regional subsiding basin, may negate local uplift from lithospheric flexure altogether (Belknap and Kraft, 1977; Cronin, 1981).

Hydroisostasy, coastal uplift from eustatic loading of the ocean basins, is perhaps a more likely mechanism because it operates over time scales of thousands of years. The depth of the Wisconsin regression along parts of the U.S. Atlantic continental shelf has been questioned (Dillon and Oldale, 1978), but if it is assumed that sea levels have risen $100 \mathrm{~m}$ since deglaciation, the amount of uplift that theoretically could be expected from hydroisostasy is only about $15 \mathrm{~m}$ (Walcott, 1972). Some of this uplift would presumably be offset by postglacial collapse of the forebulge and by onset of the relaxation period of the hydroisostatic process itself (Cronin, 1981). At present, submergence in the lower Delmarva Peninsula (largely due to subsidence) averages $40 \mathrm{~cm} / 100 \mathrm{yr}$ (Holdahl and Morrison, 1974).

Hence, if present rheological models do not adequately account for the middle Wisconsin sea-level high described along the U.S. east coast, then a reexamination of accepted models of glacioeustatic fluctuations during the Wisconsin Glaciation may be necessary. There is sufficient evidence, apart from dated transgressive sequences like Mockhorn Island, in the form of ice-free conditions (tentatively determined) in Hudson Bay ca. $35 \mathrm{ka}$ (Andrews et al., 1983), glaciological models, and uncertainties of middle Wisconsin ice cover (cf. Andrews et al., 1983) to support the strong possibility of a sea-level high during this interval. The existence of a middle Wisconsin eustatic sea-level high near modern sea level should thus rest on the validity of the evidence rather than be tailored to meet existing glacioeustatic models; however, demonstrating a eustatic signal may ultimately prove elusive because of the unique character of local sea-level records.

\section{REFERENCES CITED}

Andrews, J.T., Shilts, W.W., and Miller, G.H., 1983, Multiple deglaciation of the Hudson Bay Lowlands, Canada, since deposition of the Missinaibi (Lastinterglacial?) Formation: Quaternary Research, v. 19, p. 18-37.

Belknap, D.F., and Kraft, J.C., 1977, Holocene relative sea-level changes and coastal stratigraphic units on the northwest flank of the Baltimore Canyon trough geosyncline: Journal of Sedimentary Petrology, v. 47, p. 610-629.

Belknap, D.F., and Wehmiller, J.F., 1980, Amino acid racemization in Quaternary mollusks: Examples from Delaware, Maryland and Virginia, in Hare, P.E., Hoering, T.C., and King, K., Jr., eds., Biogeochemistry of amino acids: New York, John Wiley, p. 401-414.

Birks, H.J.B., and Peglar, S.M., 1980, Identification of Picea pollen of late Quaternary age in eastern North America: A numerical approach: Canadian Journal of Botany, v. 58, p. 2043-2058.

Blackwelder, B.W., Pilkey, O.H., and Howard, J.D., 1979, Late Wisconsinan sea levels on the southeast U.S. Atlantic shelf based on in-place shoreline indicators: Science, v. 204, p. 618-620.

Bloom, A.L., 1983, Sea level and coastal morphology of the United States through the late Wisconsin glacial maximum, in Wright, H.E., Jr., and Porter, S.C. eds., Late-Quaternary environments of the United States: Minneapolis, University of Minnesota Press, p. 215-229.

Cronin, T.M., 1981, Rates and possible causes of neotectonic vertical crustal movements of the emerged southeastern United States Atlantic Coastal Plain: Geological Society of America Bulletin, v. 92, p. 812-833.

Cronin, T.M., Szabo, B.J., Ager, T.A., Hazel, J.E., and Owens, J.P., 1981, Quaternary climates and sea levels of the U.S. Atlantic Coastal Plain: Science, v. 211, p. 233-240.

Curray, J.R., 1965, Late Quaternary history, continental shelves of the United States, in Wright, H.E., Jr., and Frey, D.G., eds., The Quaternary of the United States: Princeton, New Jersey, Princeton University Press, p. 725-735.
Dillon, W.P., and Oldale, R.N., 1978, Late Quaternary sea-level curve: Reinterpretation based on glaciotectonic influence: Geology, v. 6, p. 56-60.

Finkelstein, K., 1986, The late Quaternary evolution of a twin barrier island complex, Cape Charles, Virginia [Ph.D. thesis]: Gloucester Point, Virginia Institute of Marine Science, $284 \mathrm{p}$.

Holdahl, S.R., and Morrison, N.L., 1974, Regional investigations of vertical crustal movements in the U.S., using relevelings and mareograph data: Tectonophysics, v. 23, p. 373-390.

Hoyt, J.H., and Hails, J.R., 1974, Pleistocene stratigraphy of southeastern Georgia, in Oaks, R.Q., and DuBar, J.R., eds., Post-Miocene stratigraphy, central and southern Atlantic Coastal Plain: Logan, Utah State University Press, p. 191-205

Johnson, G.H., 1976, Geology of the Mulberry Island, Newport News North, and Hampton quadrangles, Virginia: Richmond, Virginia Division of Mining Resources Report of Investigations 41, $72 \mathrm{p}$.

Milliman, J.D., and Emery, K.O., 1968, Sea levels during the past 35,000 years: Science, v. 162, p. 1121-1123.

Mixon, R.B., 1985, Stratigraphic and shallow sub-surface geologic studies in the emerged coastal plain of the middle Atlantic states: U.S. Geological Survey Professional Paper 1067-G, 53 p.

Moslow, T.F., 1980, Stratigraphy of mesotidal barrier islands [Ph.D. thesis]: Columbia, University of South Carolina, $187 \mathrm{p}$.

Nunn, P.D., 1986, Implications of migrating geoid anomalies for the interpretation of high-level coral reefs: Geological Society of America Bulletin, v. 97, p. 946-952.

Oaks, R.Q., Jr., and Coch, N.K., 1973, Post-Miocene stratigraphy and morphology, southeastern Virginia: Richmond, Virginia Division of Mineral Resources Bulletin $82,135 \mathrm{p}$.

Owens, J.P., and Denny, C.S., 1979, Upper Cenozoic deposits of the central Delmarva Peninsula: U.S. Geological Survey Professional Paper 1067-A, 28 p.

Poag, C.W., Knebel, H.J., and Todd, R., 1980, Distribution of modern benthic foraminifers on the New Jersey outer continental shelf: Marine Micropaleontology, v. 5, p. 43-69.

Ruddiman, W.F., and McIntyre, A., 1981, Oceanic mechanisms for amplification of the 23,000 year ice-volume cycle: Science, v. 212, p. 617-627.

Shackleton, N.J., and Opdyke, N.D., 1973, Oxygen isotope and paleomagnetic stratigraphy and equatorial Pacific core V28-238: Oxygen isotope temperatures and ice volumes on a $10^{5}$ and $10^{6}$ year scale: Quaternary Research, v. 3, p. 39-55.

Shideler, G.L., Ludwick, J.C., Oertel, G.F., and Finkelstein, K., 1984, Quaternary stratigraphic evolution of the southern Delmarva Peninsula coastal zone, Cape Charles, Virginia: Geological Society of America Bulletin, v. 95, p. 489-502.

Sirkin, L.A., Denny, C.S., and Rubin, M., 1977, Late Pleistocene environment of the central Delmarva Peninsula, Delaware-Maryland: Geological Society of America Bulletin, v. 88, p. 139-142.

Susman, K.R., and Heron, S.D., 1979, Evolution of a barrier island-Shackleford Banks, Carteret County, North Carolina: Geological Society of America Bulletin, v. 90, p. 205-215.

Szabo, B.J., 1985, Uranium series dating of fossil corals from marine sediments of southeastern United States Atlantic Coastal Plain: Geological Society of America Bulletin, v. 96 , p. 398-406.

Thom, B.G., 1973, Dilemma of high interstadial sea levels during the last glaciation: Progress in Geography, v. 5, p. 167-246.

Walcott, R.I., 1972, Past sea levels, eustasy and deformation of the earth: Quaternary Research, v. 2, p. 1-14.

Weimer, R.J., and Hoyt, J.H., 1964, Burrows of Callianassa major Say, geologic indicators of littoral and shallow neritic environments: Journal of Paleontology, v. 38, p. 761-767.

Whitehead, D.R., 1981, Late-Pleistocene vegetational changes in northeastern North Carolina: Ecology, v. 51, p. 451-471.

Williams, D.F., Moore, W.S., and Fillon, R.H., 1981, Role of glacial Arctic Ocean ice sheets in Pleistocene oxygen isotope and sea level records: Earth and Planetary Science Letters, v. 56, p. 157-166.

\section{ACKNOWLEDGMENTS}

We thank L. D. Wright, G. H. Johnson, and S. P. Leatherman for helpful criticisms of this paper. Some of this research was carried out under the auspices of the Barrier Island Sedimentation Studies Work Unit at the U.S. Army Coastal Engineering Research Center. Virginia Institute of Marine Science Contribution 1416.

Manuscript received March 30, 1987

Revised manuscript received September 22, 1987

Manuscript accepted October 20, 1987 